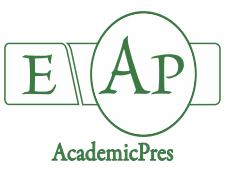

Jankauskienè J et al. (2021)

Notulae Botanicae Horti Agrobotanici Cluj-Napoca

Volume 49, Issue 1, Article number 12267

DOI: $10.15835 /$ nbha49112267

Research Article

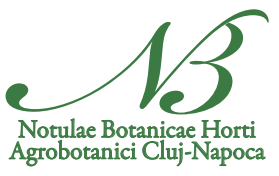

\title{
Potential of vegetable soybean cultivation in Lithuania
}

\author{
Jule JANKAUSKIENE**, Aušra BRAZAITYTÉ, \\ Viktorija VAŠTAKAITÉ-KAIRIENÉ
}

Institute of Horticulture, Lithuanian Research Centre for Agriculture and Forestry, Kauno str. 30, Babtai, Kaunas distr., Lithuania; jule.jankauskiene@lammc.lt ("*orrespondingauthor); ausra.brazaityte@lammc.lt; viktorija.vastakaite-kairiene@lammc.lt

\begin{abstract}
The objective of the present study was to investigate the potential of vegetable soybean (Edamame) cultivation in Lithuania. Six soybean varieties were grown in an open field. Our data showed that the plants of the 'Chiba Green' variety were the shortest. Such plants had higher chlorophyll index and photosynthesis intensity. Variety 'Midori Giant' had more branches than plants of other varieties. The highest yield was produced by the plants of the 'Chiba Green' variety. Higher protein content was found in beans of the 'Chiba Green' variety. However, there were no differences found in soluble carbohydrates and micro- and macroelement contents between the varieties. In summary, the results revealed that of the tested varieties, the most suitable and useful for the cultivation under Lithuanian climate conditions was the 'Chiba Green' vegetable soybean variety.
\end{abstract}

Keywords: cultivation opportunities; Edamame; protein; soluble carbohydrates; yield

\section{Introduction}

In a changing climate, there are possibilities to grow plants in Lithuania and in the northern regions of other countries (northern Florida, North Dakota) that are normally grown in warmer regions and have high nutritional value. One of such plants could be vegetable soybeans. The legume family to which vegetable soybeans belongs consists of approximately 20000 species. This is the third-largest group of flowering plants, to which other important legumes, e. g. peas (Phaseolus vulgaris), mung bean (Vigna radiata) and pigeon pea (Cajanus cajan) belong (Lee et al., 2015). Edamame or vegetable soybean (Glycine max L. Merrill), is a group of special cultivars of soybean. It is a self-pollinating, annual plant similar to beans. Vegetable soybean is a low input, short crop cycle and soil-enriching crop (Zhang et al., 2017). The optimum time to harvest edamame is when the pods are still green or become yellow, immature (at R6 stage - full seed), and tight with fully developed immature green seeds, usually at 80-90\% pod fill (Fehr and Caviness, 1977; Wang et al., 2005; Zhang et al., 2010). At this stage the flavor of edamame is nutty, sweet, buttery and beany (Wszelaki et al., 2005).

Edamame has been highly valued in the human diet. It is rich in vitamins B and C, has calcium, iron, zinc, food fibre and protein. It is an excellent source of antioxidants and isoflavones (Medic et al., 2014). In terms of protein content, soybeans are ahead of other protein crops and are only less inferior to meat and eggs.

Edamame is becoming increasingly popular worldwide (Medic et al., 2014; Zeipina et al., 2017). In recent decades, the demand for vegetable soybean has grown significantly due to its nutritional properties and

Received: 12 Feb 2021. Received in revised form: 01 Mar 2021. Accepted: 10 Mar 2021. Published online: 24 Mar 2021.

From Volume 49, Issue 1, 2021, Notulae Botanicae Horti Agrobotanici Cluj-Napoca journal will use article numbers in place of the traditional method of continuous pagination through the volume. The journal will continue to appear quarterly, as before, with four annual numbers. 
the growing demand for healthy food (Zhang et al., 2017). In countries such as Argentina, Australia, Israel, Mongolia, North American countries, New Zealand, and Thailand, edamame is widely grown for commercial purposes (Wang et al., 2005). Vegetable soybean is one of the main crops in Korea, which is the third after rice and wheat (Lee et al., 2015). The consumption of vegetable soybeans is rapidly increasing in Japan, Korea, China and Taiwan, and now gaining popularity as a fresh vegetable throughout the United States (Zhang and Kyei-Boahen, 2007). To meet growing demand, edamame is imported frozen from China and Taiwan into the U.S. (Nolen et al., 2016).

Edamame cultivation opportunities have been explored in many regions - in central Pennsylvania (Sanchez et al., 2005), in the Mississippi Delta (Zhang and Kyei-Boahen, 2007), in the mid-Atlantic United States (Carson et al., 2011), in Central Alabama (Ogles et al., 2016). It was also studied the possibilities of edamame genotypes for growing in the northern regions of some countries - in North Dakota (Duppong and Hatterman-Valenti, 2005), in northern Florida (Guo et al., 2020). The results from these studies indicated that vegetable soybean could be successfully grown in these areas. In the first half of the 20th century, P. Dindonis researched soybean varieties in Latvia; however, they did not become popular in that country. In 2015, the research on soybean cultivation possibilities in Latvia was carried out in Püre Horticultural Research Centre. Five Japanese soybean cultivars were grown and their productivity was determined (Zeipina et al., 2016). According to research data higher yield was obtained for the 'Mizon Giant' plant.

Different soybean varieties are sensitive to changes in environmental conditions. It is necessary to investigate the interaction between a genotype and the environment to identify varieties that are stable in different environments (Calviño et al., 2003). For edamame cultivation to be commercially viable, growers need to know which varieties are suitable for cultivation in a given area, i.e. it is important to select varieties suitable for the climate of each area and to know the peculiarities of their cultivation (Zhang et al., 2017; Nagasuga, 2018; Djanta et al., 2020). These vegetable soybeans are still a novelty in Lithuania no data on their cultivation have been found. Soy is a very light-sensitive plant. Day length and light intensity are important for flowering and the growing season length, affecting growth, height and, undoubtedly, yield. Varieties that need less light and heat are already being grown in Lithuania. The diversity of these plant varieties is considerable, differing in height and earliness. Therefore, it is not known which varieties are suitable for cultivation in Lithuania, what their vegetation period, nutritional value and productivity are.

We hypothesize that choosing vegetable soybean varieties suitable for the Lithuanian climate would provide an opportunity to expand the assortment of protein-rich food plants.

The work objective was to select vegetable soybean varieties suitable for growing under Lithuanian conditions and to determine the nutritional value indicators in soybeans.

\section{Materials and Methods}

\section{Growing conditions}

The experiments were carried out at the Institute of Horticulture, Lithuanian Research Centre for Agriculture and Forestry in 2015-2016. Six varieties of vegetable soybeans were investigated: 'Aoshizuku' (Japan), 'Chiba Green' (USA), 'Kaohsiung No9' (Japan), 'Midori Giant'(USA), 'Sapporomidori' (Japan) and 'Sayamusume' (Japan).

The experiment was conducted on Idg8-k Calc(ar)i - Epihypogleyic Luvisolls (LVg-p-w-cc) (WRB, 2014), texture - sandy with sandy clay loam in deeper layers. The soil, on which the soya was grown, was low in nitrogen $\left(37.3-38.5 \mathrm{~kg} \mathrm{ha}^{-1}\right)$, average humus content $(2.76 \%)$, rich in available phosphorus as $\mathrm{P}_{2} \mathrm{O}_{5}(181-214$ $\left.\mathrm{mg} \mathrm{kg}{ }^{-1}\right)$, averagely rich in potassium as $\mathrm{K}_{2} \mathrm{O}\left(121-122 \mathrm{mg} \mathrm{kg}^{-1}\right)$, and rich in calcium and magnesium. Soil $\mathrm{pH}_{\mathrm{KCl}}$ - 7.5. The soybean was sown in rows at $70 \mathrm{~cm}$ spacing. Plot area: $3.50 \times 2.80=9.8 \mathrm{~m}^{2}$, record plot area $-4.9 \mathrm{~m}^{2}$. The experiment was conducted with three replications, arranged randomly. During the growing season 
mechanical chisel loosening was used between rows. The soya was seeded at the end of May and harvested at the end of September 2015 and at the beginning of October 2016.
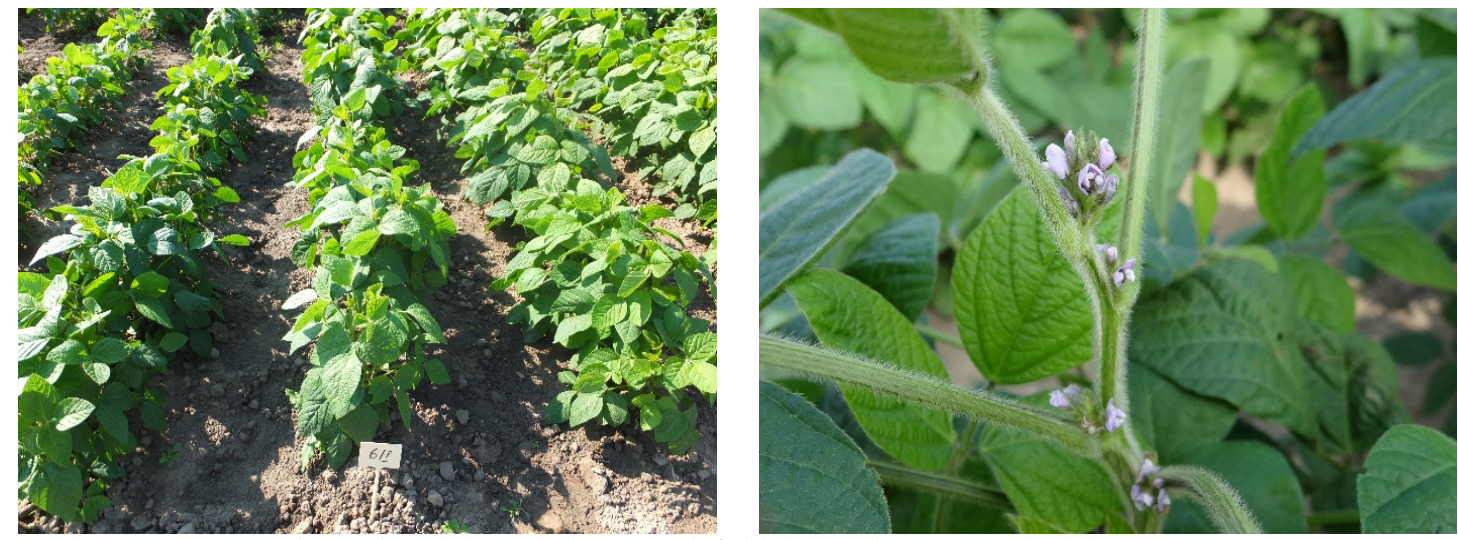

Figure 1. Vegetable soybean plants in the research field during the experiments

\section{Biometric measurements}

Phenological and biometric observations were carried out. During vegetation the plant height at flowering (plant height was measured up to an inflorescence) was measured and the number of branches per plant was calculated. These measurements were performed in ten replicates $(n=10)$. The edamame yield per plant was recorded at the end of the harvest. The weight of 100 pods ( $2-3$ beans per pod) and 25 seeds were determined.

\section{Determination of photosynthetic indices}

Non-destructive measurements of leaf chlorophyll content were performed using a chlorophyll and flavonoid meter (Dualex ${ }^{\circ}$, Scientific, USA). The first fully matured leaves of 10 plants per treatment were measured.

\section{Determination of photosynthetic intensity}

The photosynthetic rate was determined at 9:00-12:00 am by using an LI-6400XT portable open flow gas exchange system (Li-COR Biosciences, Lincoln, USA). Reference air $\left[\mathrm{CO}_{2}\right]\left(400 \mu \mathrm{mol} \mathrm{mol}^{-1}\right)$, light intensity $\left(1000 \mu \mathrm{mol} \mathrm{m}^{-2} \mathrm{~s}^{-1}\right)$ and the flow rate of gas pump $\left(500 \mathrm{mmol} \mathrm{s}^{-1}\right)$ were set.

\section{Determination of soluble carbohydrates}

Concentrations of water-soluble carbohydrates (WSC) in water extracts of dried samples were measured spectrophotometrically using the anthrone reagent. We prepared stock standards and working standards. Stock standard: $100 \mathrm{mg}$ glucose was weighed and carefully added to $100 \mathrm{ml}$ distilled water $(100 \mathrm{mg}$ glucose per 100 $\mathrm{ml}$ distilled water). Working standard: $10 \mathrm{ml}$ of stock standard solution was diluted in $100 \mathrm{ml}$ distilled water in a volumetric flask. We took 0.2 to $1 \mathrm{ml}$ of working standard solution from five different tubes and added water to make up $1 \mathrm{ml}$ per tube, then added $4 \mathrm{ml}$ of anthron reagent $(200 \mathrm{mg}$ of anthron reagent was dissolved in $100 \mathrm{ml}$ of concentrated $\mathrm{H}_{2} \mathrm{SO}_{4}$ ) and mixed the contents. We covered the tube for 10 minutes, then the tube was cooled to room temperature and we measured the optical density using a red filter by a photoelectric colorimeter at $620 \mathrm{~nm}$. At the same time, a blank solution was prepared to contain $1 \mathrm{ml}$ of distilled water and $4 \mathrm{ml}$ of anthrone reagent. The calibration curve was plotted. From the calibration curve, we calculated the sugar concentration in the sample. 


\section{Determination of protein}

Protein content was determined by the Kjeldahl method. Approximately $1 \mathrm{~g}$ of raw material was hydrolyzed with $15 \mathrm{~mL}$ concentrated sulfuric acid $\left(\mathrm{H}_{2} \mathrm{SO}_{4}\right)$ containing two copper catalyst tablets in a heat block (Kjeltec system 2020 digestor, Tecator Inc., Herndon, VA, USA) at $420{ }^{\circ} \mathrm{C}$ for $2 \mathrm{~h}$. After cooling, $\mathrm{H}_{2} \mathrm{O}$ was added to the hydrolysates before neutralization and titration. The amount of total nitrogen in the raw materials was multiplied with both the traditional conversion factor of 6.25 and species-specific conversion factors to determine total protein content.

\section{Determination of macro- and microelements}

The contents of macro- and microelements in vegetable soybeans were determined using the microwave digestion technique combined with inductively coupled plasma optical emission spectrometry. Complete digestion of dry vegetable soybean matter $(0.5 \mathrm{~g})$ was achieved with $65 \% \mathrm{HNO}_{3}$ and $30 \% \mathrm{H}_{2} \mathrm{O}_{2}$ (5:3) using the microwave digestion system Multiwave GO (Anton Paar GmbH, Austria). The digestion program was as follows: 1) $150^{\circ} \mathrm{C}$ reached within $3 \mathrm{~min}$, digested for $10 \mathrm{~min}$; and 2) $180^{\circ} \mathrm{C}$ reached within $10 \mathrm{~min}$, digested for $10 \mathrm{~min}$. The mineralised samples were diluted to $50 \mathrm{~mL}$ with deionized water. The elemental profile was analysed by ICP - OES spectrometer (Spectro Genesis, SPECTRO Analytical Instruments, Germany). The operating conditions employed for ICP-OES determination were $1300 \mathrm{~W}$ RF power, $12 \mathrm{~L} \mathrm{~min}^{-1}$ plasma flow, $1.0 \mathrm{~L} \mathrm{~min}^{-1}$ auxiliary flow, $0.8 \mathrm{~L} \mathrm{~min}^{-1}$ nebulizer flow, and $1.0 \mathrm{~mL} \mathrm{~min}{ }^{-1}$ sample uptake rate. The analytical wavelengths (nm) chosen were: B I $249.773 \mathrm{~nm}$, Ca II $445.478 \mathrm{~nm}$, Cu I $324.754 \mathrm{~nm}$, Fe II $259.941 \mathrm{~nm}$, K I $766.491 \mathrm{~nm}, \mathrm{Mg}$ II $279.079 \mathrm{~nm}, \mathrm{Mn}$ II $259.373 \mathrm{~nm}, \mathrm{Na}$ I $589.592 \mathrm{~nm}$, P I $213.618 \mathrm{~nm}$, S I $182.034 \mathrm{~nm}$, and $\mathrm{Zn}$ I $213.856 \mathrm{~nm}$. The calibration standards were prepared by diluting a stock multi-elemental standard solution $\left(1000 \mathrm{mg} \mathrm{L}^{-1}\right)$ in $6.5 \%(\mathrm{v} / \mathrm{v})$ nitric acid, and by diluting stock phosphorus and sulphur standard solutions $\left(1000 \mathrm{mg} \mathrm{L}^{-1}\right)$ in deionized water. The calibration curves for all the studied elements were in the range of $0.01-400 \mathrm{mg} \mathrm{L}^{-1}$.

\section{Statistical analysis}

Data were tested using one-way analysis of variance and the means were compared by Tukey's least significant differences (LSD). Statistical significance was evaluated at $\mathrm{p} \leq 0.05$. The correlation coefficient was determined by the statistical method of path coefficient analysis using STAT-ENG programme.

\section{Results}

The average air temperature of May-July 2015 was close to the multiannual average (Table 1). August was particularly warm; the air temperature was $3^{\circ} \mathrm{C}$ higher than the multiannual average. In September, the air temperature was also above the multiannual average. During the vegetation period of 2016 , the air temperature was above the multiannual average. In May-July 2016 the air temperature was $0.9-3.6^{\circ} \mathrm{C}$ higher compared to the same months of 2015. In June and August 2015, when humidity was necessary for plant growth, it was very dry. July 2016 was particularly rainy; precipitation was $15.9 \mathrm{~mm}$ above the multiannual average. The precipitation in May and September was significantly lower than the multiannual average.

During both years, the soybean germinated 6 days after sowing (Table 2). The best germination showed by the 'Aoshizuku' variety. The plants of all soybean varieties developed similarly, except the 'Aoshizuku' variety. At the time of flowering of other varieties (R2 stage - full flowering), 'Aoshizuku' plants began to form buds (R1 stage - beginning flowering). The plants of the 'Aoshizuku' variety began to form pods, while the plants of other varieties began to form seeds. Thus, the development of this cultivar was behind other cultivars at one stage of growth. The plants of the 'Aoshizuku' variety did not produce seeds and were not harvested. In both years the duration of the vegetation period varied little. In 2015 the duration of the soybean vegetation period was 117 days, while in 2016 it was slightly longer - 126 days. 
Table 1. Air temperature and precipitation amount

\begin{tabular}{|c|c|c|c|c|c|c|}
\hline \multirow{2}{*}{ Month } & \multicolumn{3}{|c|}{ Air temperature $\left({ }^{\circ} \mathrm{C}\right)$} & \multicolumn{3}{c|}{ Precipitation (mm) } \\
\cline { 2 - 7 } & 2015 & 2016 & Multiannual & 2015 & 2016 & Multiannual \\
\hline May & 12.0 & 15.6 & 12.3 & 63.2 & 11.2 & 50.7 \\
\hline June & 15.9 & 17.4 & 15.9 & 26.8 & 45.8 & 71.2 \\
\hline July & 17.6 & 18.5 & 17.3 & 91.2 & 107.6 & 75.3 \\
\hline August & 19.7 & 17.4 & 16.7 & 4.6 & 77.4 & 78.4 \\
\hline September & 14.0 & 13.6 & 12.1 & 43.4 & 13.4 & 58.7 \\
\hline
\end{tabular}

Data of Babtai agrometeorological station, using iMETOS program. Babtai

Table 2. Duration of growth stages of different vegetable soybean varieties (the number of days)

\begin{tabular}{|c|c|c|c|c|c|c|}
\hline Growth stages & 'Aoschizuku' & $\begin{array}{c}\text { 'Chiba } \\
\text { green' }\end{array}$ & $\begin{array}{c}\text { 'Kaohsiung } \\
\text { No9' }\end{array}$ & $\begin{array}{c}\text { 'Midori } \\
\text { Giant' }\end{array}$ & $\begin{array}{c}\text { 'Sapporo- } \\
\text { midori' }\end{array}$ & 'Saymusume' \\
\hline Seeding-VE & 7 & 7 & 7 & 7 & 7 & 7 \\
\hline VE & 6 & 7 & 7 & 7 & 7 & 7 \\
\hline Germination & 6 & 7 & 7 & 7 & 7 & 7 \\
\hline VC-V1 & 11 & 11 & 11 & 11 & 11 & 11 \\
\hline V1-V2 & 10 & 10 & 10 & 10 & 10 & 10 \\
\hline V3 & 8 & 7 & 7 & 7 & 7 & 7 \\
\hline V3-R1 & 25 & 7 & 7 & 7 & 7 & 7 \\
\hline R1 & 9 & 18 & 18 & 18 & 18 & 7 \\
\hline R2 & 14 & 7 & 7 & 7 & 7 & 9 \\
\hline R3 & 6 & 9 & 9 & 9 & 9 & 15 \\
\hline R4-R7 & 20 & 15 & 15 & 15 & 15 & 20 \\
\hline R8 & - & 20 & 20 & 20 & 20 & 7 \\
\hline
\end{tabular}

Growth stages: VE - emergence, VC - cotyledon, V1 - first node, V2 - second node, V3 - third node, R1 - beginning flowering, R2 - full flowering, R3 - begining pod, R4 - full pod, R5 -begining seed, R6 - full seed, R7 - beginning maturity, R8 - full maturity

The results of biometric measurements of different vegetable soybean varieties are shown in Table 3. In 2015 , the soybean plants of all varieties were shorter than in 2016. During both years of the study, the highest plants of the studied soybean cultivars were those of 'Kaohsiung No9'. They were 9.9-40.8\% higher compared to other cultivars, respectively. 'Chiba Green' soybean plants were the shortest during both years of the study. The plants of this variety were compact, the branches arranged in one plane. The plants of 'Midori Giant' and 'Kaohsiung No9' cultivars formed more branches during both years of the study compared to other cultivars. The 'Aoshizuku' plants formed the least number of branches.

Table 3. Vegetable soybean plant height and number of branches

\begin{tabular}{|c|c|c|c|c|c|c|}
\hline \multirow{2}{*}{ Varieties } & \multicolumn{3}{|c|}{ Plant height $(\mathrm{cm})$} & \multicolumn{3}{c|}{ Number of branches (units) } \\
\cline { 2 - 7 } & 2015 & 2016 & Average & 2015 & 2016 & Average \\
\hline 'Aoshizuku' & 44.67 & $46.23^{\mathrm{B}}$ & 45.45 & $3.33^{\mathrm{B}}$ & $3.00^{\mathrm{B}}$ & $3.17^{\mathrm{B}}$ \\
\hline 'Chiba Green' & $34.93^{\mathrm{B}}$ & $44.03^{\mathrm{B}}$ & $39.48^{\mathrm{B}}$ & 4.00 & 4.00 & 4.00 \\
\hline 'Kaohsiung No9' & $50.03^{\mathrm{A}}$ & $61.17^{\mathrm{A}}$ & $55.60^{\mathrm{A}}$ & 4.33 & 4.00 & $4.17^{\mathrm{A}}$ \\
\hline 'Midori Giant' & 42.70 & $58.50^{\mathrm{A}}$ & 50.60 & $4.67^{\mathrm{A}}$ & $4.33^{\mathrm{A}}$ & $4.50^{\mathrm{A}}$ \\
\hline 'Sapporomidori' & 38.20 & 48.90 & 43.55 & 3.67 & 3.30 & $3.49^{\mathrm{B}}$ \\
\hline 'Sayamusume' & 42.20 & 54.43 & 48.32 & 4.00 & 3.67 & 3.84 \\
\hline LSD $_{05}$ & 4.94 & 3.75 & 5.56 & 0.61 & 0.51 & 0.16 \\
\hline
\end{tabular}

A - significantly $(p>0.05)$ more than the average; B - significantly less than the average

Note: measured to the last inflorescence on the main stem 

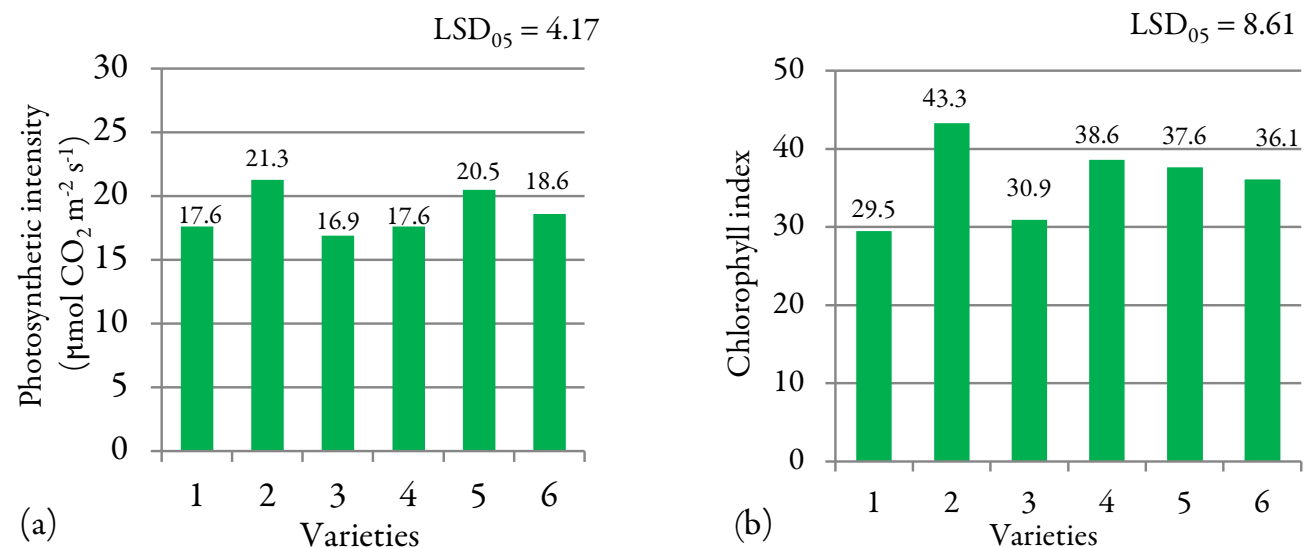

Figure 2. Photosynthetic intensity (a) and chlorophyll index (b) in the leaves of different varieties of vegetable soybean

( 1 - Aoshizuku, 2 - Chiba Green, 3 - Kaohsiung No9, 4 - Midori Giant, 5 - Sapporomidori, 6 - Sayamusume) (average of 2015-2016)

The photosynthetic intensity in soybean plants varied between varieties (Figure 1a). 'Chiba Green' cultivars showed the highest photosynthetic intensity (significantly more than in the leaves of the Kaohsiung variety). The photosynthetic intensity of 'Sapporomidori' cultivars was slightly lower than that of 'Chiba Green' plants. The photosynthetic intensity in 'Aoshizuku', 'Midori Giant' plants was the same. The plants of the 'Kaohsiung No9' soybean variety had the lowest photosynthetic intensity. Chlorophyll index in soybean leaves varied depending on the variety (Figure 1b). The leaves of the 'Chiba Green' variety showed the highest chlorophyll indexes (significantly more than in the 'Aoshizuku' and 'Kaohsiung No9' leaves). In the leaves of 'Midori Giant', 'Sapporomidori', and 'Sayamusume' the chlorophyll indexes were similar.

The contents of elements in soybeans depended on the variety (Table 4). The highest potassium content was found in 'Midori Giant' soybean seeds (significant difference) and the highest calcium was determined in 'Sapporomidori' seeds (significant difference). Magnesium content was the highest in the seeds of the 'Sayamusume' variety. There was little difference in iron and zinc contents in the soybean cultivars studied. 'Chiba Green' plants accumulated the lowest levels of potassium, calcium, magnesium and phosphorus in their seeds.

Table 4. Element contents in the seeds of different varieties of vegetable soybean (average of 2015-2016)

\begin{tabular}{|c|c|c|c|c|c|c|}
\hline \multirow{2}{*}{ Varieties } & \multicolumn{7}{|c|}{ Elements $\left(\mathrm{mg} \mathrm{g}^{-1}\right)$} \\
\cline { 2 - 7 } & $\begin{array}{c}\text { Potasium } \\
(\mathrm{K})\end{array}$ & $\begin{array}{c}\text { Calcium } \\
(\mathrm{Ca})\end{array}$ & $\begin{array}{c}\text { Magnesium } \\
(\mathrm{Mg})\end{array}$ & $\begin{array}{c}\text { Phosphorus } \\
(\mathrm{P})\end{array}$ & $\begin{array}{c}\text { Iron } \\
(\mathrm{Fe})\end{array}$ & $\begin{array}{c}\text { Zinc } \\
(\mathrm{Zn})\end{array}$ \\
\hline 'Chiba Green' & 34.14 & $1.27^{\mathrm{B}}$ & $17.76^{\mathrm{B}}$ & 6.98 & 0.41 & 0.31 \\
\hline 'Kaohsiung No9' & 34.96 & 1.47 & $18.41^{\mathrm{B}}$ & 7.68 & 0.39 & 0.32 \\
\hline 'Midori Giant' & $36.31^{\mathrm{A}}$ & 1.59 & 18.82 & 7.41 & 0.38 & 0.32 \\
\hline 'Sapporomidori' & 34.71 & $2.01^{\mathrm{A}}$ & $21.96^{\mathrm{A}}$ & 7.14 & 0.40 & 0.30 \\
\hline 'Sayamusume' & 35.48 & 1.90 & $22.20^{\mathrm{A}}$ & 7.32 & 0.39 & 0.30 \\
\hline LSD $_{05}$ & 1.06 & 0.19 & 1.32 & 0.42 & 0.06 & 0.02 \\
\hline
\end{tabular}

A - significantly ( $>0.05)$ more than the average; $B$ - significantly less than the average

Soybean yield depended on the year and the variety (Table 5). The plants of 'Chiba Green' and 'Kaohsiung No9' cultivars were more productive in 2015, and in 2016 the yield of these plants was lower. The plants of 'Midori Giant', 'Sapporomidori', and 'Sayamusume' were more productive in 2016 compared to the yield of the same varieties obtained in 2015. The soybean variety 'Chiba Green' had the highest yield per plant 
(significant difference) during both years of the study (Table 5). The yield per plant from 'Kaohsiung No9', 'Sapporomidori' and 'Sayamusume' varieties was almost the same. In terms of pod yield per plant, the soya varieties lined up as follows: 'Chiba Green'> 'Midori Giant'> 'Sapporomidori'> 'Sayamusume'> 'Kaohsiung No9'.

Table 5. Pod yield of different varieties of vegetable soybean

\begin{tabular}{|c|c|c|c|}
\hline \multirow{2}{*}{ Varieties } & \multicolumn{3}{|c|}{ Yield $\left(\mathrm{kg} \mathrm{plant}^{-1}\right)$} \\
\cline { 2 - 4 } & 2015 & 2016 & Average \\
\hline 'Chiba Green' & $0.173^{\mathrm{A}}$ & $0.166^{\mathrm{A}}$ & $0.170^{\mathrm{A}}$ \\
\hline 'Kaohsiung No9' & 0.085 & $0.054^{\mathrm{B}}$ & 0.070 \\
\hline 'Midori Giant' & 0.083 & 0.125 & 0.104 \\
\hline 'Sapporomidori' & $0.063^{\mathrm{B}}$ & 0.089 & 0.076 \\
\hline 'Sayamusume' & $0.068^{\mathrm{B}}$ & 0.074 & 0.071 \\
\hline LSD 05 & 0.012 & 0.039 & 0.035 \\
\hline
\end{tabular}

A - significantly $(\mathrm{p}>0.05)$ more than the average; $\mathrm{B}$ - significantly less than the average

'Chiba Green' soybean plants formed the largest number of Category I (2-3 seeds per pod) (significant difference) and II ( 1 seed per pod) pods (Table 6). Depending on the variety, the yield of Category I pods was $55.7-75.3 \%$ of the total yield. The lowest number of Category I pods was obtained from 'Kaohsiung No9' cultivars. The plants of this variety formed the highest yield of Category III (non-commercial) pods. The yield of Category I pods from 'Sapporomidori' and 'Sayamusume' plants was the same.

Table 6. Harvest quality data of different varieties of vegetable soybeans (average of 2015-2016)

\begin{tabular}{|c|c|c|c|}
\hline \multirow{2}{*}{ Varieties } & \multicolumn{3}{|c|}{ Yield $\left(\mathrm{kg}\right.$ plant $\left.{ }^{-1}\right)$} \\
\cline { 2 - 4 } & Category I & Category II & Category III \\
\hline 'Chiba Green' & $0.128^{\mathrm{A}}$ & 0.037 & 0.005 \\
\hline 'Kaohsiung No9' & $0.039^{\mathrm{B}}$ & 0.022 & $0.010^{\mathrm{A}}$ \\
\hline 'Midori Giant' & 0.065 & 0.032 & 0.007 \\
\hline 'Sapporomidori' & 0.049 & 0.019 & 0.005 \\
\hline 'Sayamusume' & 0.047 & 0.017 & 0.007 \\
\hline LSD $_{05}$ & 0.020 & 0.016 & 0.002 \\
\hline
\end{tabular}

A - significantly $(\mathrm{p}>0.05)$ more than the average; B - significantly less than the average

The weight of 100 pods of the 'Chiba Green' cultivar was the highest (Figure 2a). It was 25.2-41.6\% (significant difference) higher than the weight of 100 pods of 'Midori Giant' and 'Sapporomidori' cultivars, respectively. 'Sapporomidori' cultivar had the lowest 100 pod weight. 'Kaohsiung No9' and 'Sayamusume' varieties demonstrated almost the same weight of 100 pods. The average weight of 25 seeds of edamame varieties for two years is shown in Figure 2b. The weight of 25 edamame seeds was almost the same for both years. In 2015, depending on the variety, it ranged from 31 to $52 \mathrm{~g}$, and in 2016 - from 35 to $53 \mathrm{~g}$. The 25 -seed weights of 'Chiba Green' and 'Sayamusume' soybean varieties were the highest and significantly higher compared to the 25-seed weights of 'Kaohsiung No9' and 'Midori Giant' varieties. The 25-seed weights for soybean varieties 'Kaohsiung No9' and 'Midori Giant' were the lowest.

Protein and soluble carbohydrate contents in edamame seeds are presented in Figure 3. The protein content in soybeans depended more on the variety than on the year (Figure 3a). The year of growth had the greatest effect on the protein content of 'Chiba Green' beans. In 2015, the beans of this variety accumulated 6.3\% more protein compared to 2016. In both years of the study, 'Chiba Green' soybeans accumulated the significantly highest levels of protein. The protein content of 'Midori Giant' and 'Sapporomidori' beans did not differ much and was 1.2 - 3.4\% higher, respectively, compared to that of 'Kaohsiung No9' and 'Sayamusume' beans. The latter accumulated the lowest protein content in seeds. 
The soluble carbohydrate contents in soybeans depended on the year of cultivation and the variety (Figure 3b). In 2015, all cultivated soybean varieties accumulated 5.0 - 13.5\% more soluble carbohydrates compared to 2016. However, during both years of the study, the highest levels of soluble carbohydrates were accumulated in 'Kaohsiung No9' variety soybeans (significant difference). The soluble carbohydrates contents in other varieties of beans were almost uniform and ranged from 16.1 to $16.6 \%$.
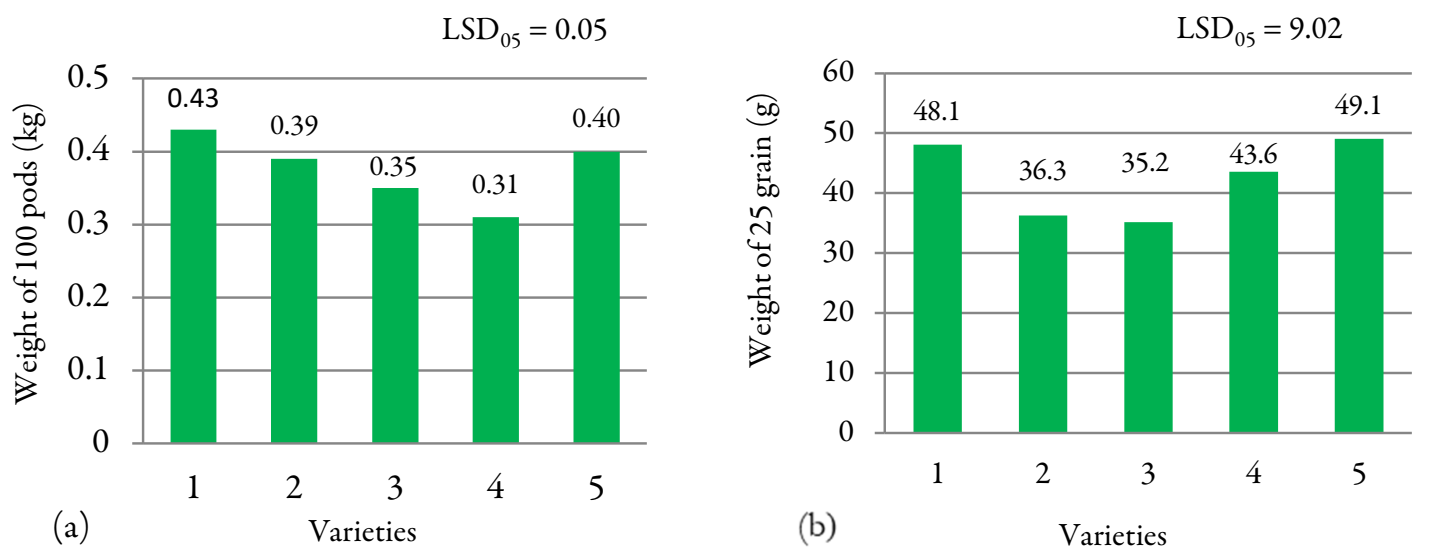

Figure 3. Weight of 100 pods (a) and 25 seeds (b) of different varieties of vegetable soybean (1 - Aoshizuku, 2 - Chiba Green, 3 - Kaohsiung No9, 4 - Midori Giant, 5 - Sapporomidori) (average of 2015-2016)
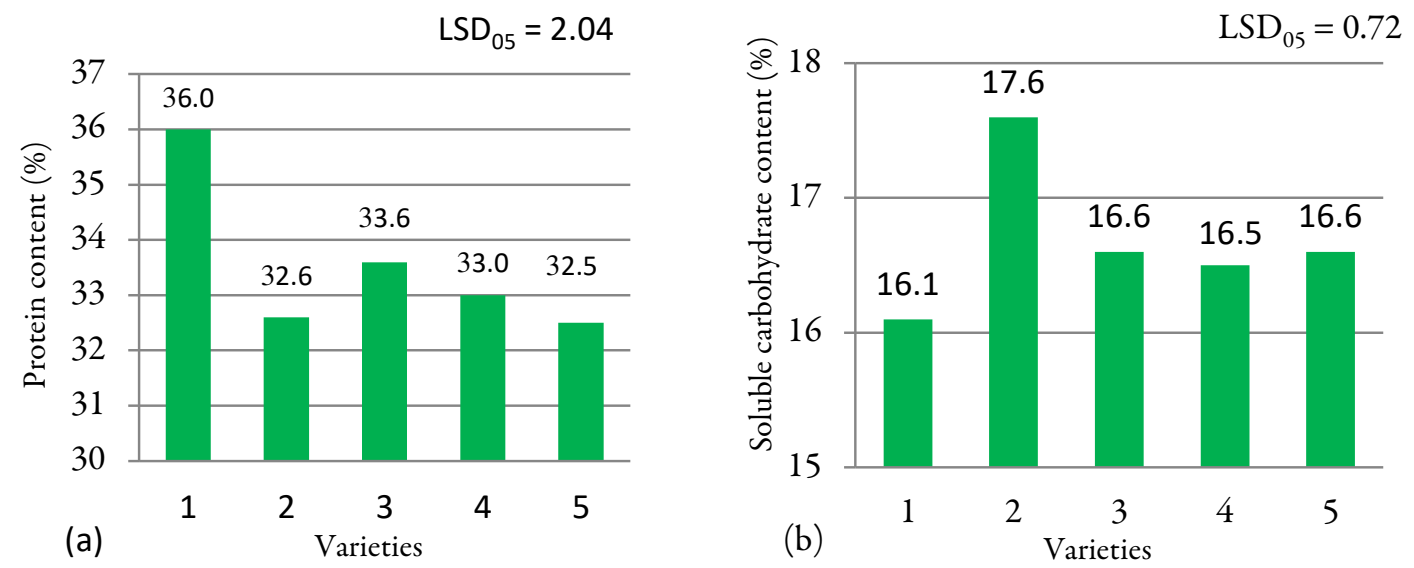

Figure 4. Protein (a) and soluble carbohydrate (b) contents in seeds of different varieties of vegetable soybean

(1 - Aoshizuku, 2 - Chiba Green, 3 - Kaohsiung No9, 4 - Midori Giant, 5 - Sapporomidori) (average of 2015-2016)

\section{Discussion}

Soybean growth, development, and yield are significantly influenced by a variety and a sowing date (Muhammad et al., 2009; Shegro et al., 2010; Santos et al., 2013; Li et al., 2014; Matsuo et al., 2016; Bakal et al., 2017). In our studies, six edamame varieties were grown; however, one of them - 'Aoshizuku' did not form pods, therefore, the crop was not harvested. The other five varieties grew and developed similarly. Plant height indicates the phenology and growth of the crop (Shah et al., 2017). The average plant height can range from 20 
to $150 \mathrm{~cm}$, depending on the environment, and is typical of the variety in question. In our studies, the height of different soybean varieties was different. Our data showed that the plants of the 'Chiba Green' variety were the shortest and the plants of the 'Kaohsiung No9' variety were the highest (Table 3). The data by Ngalamu et al. (2013) suggests that a high seed yield potential is associated with the number of branches per plant, the number of productive pods per plant and leaf area. Contrary to Ngalamu et al. data, under our conditions, 'Kaohsiung No9' and 'Midori Giant' soybean varieties formed more branches, but their yield was lower than that of soybean which had fewer branches.

The process of plant photosynthesis is usually associated with higher yields; however, the relationship between them is not clear. It is believed that photosynthetic intensity depends on the earliness of a variety. Early cultivars had higher peak rates of photosynthesis compared to those of later-maturing cultivars. However, the rate of photosynthesis in early-maturing cultivars decreased rapidly after reaching the peak, while the leaves of later cultivars retained their photosynthetic activity for much longer (Nagasuga, 2018). According to our data, the photosynthetic intensity of the investigated soybean plants was different (Figurela). 'Chiba Green' cultivars had the highest photosynthetic intensity, and the chlorophyll index was the highest in the leaves of these plants (Figure 1a, b). Besides, these plants were the most productive. Therefore, it can be argued that photosynthetic intensity influences the yields.

The chemical composition of soybeans depends on genetic and environmental factors. The main mineral elements in soybeans are calcium, phosphorus, potassium, and they also contain zinc, copper, iron, and manganese (Gupta et al., 1976). Biel et al. (2018) stated that the content of mineral elements in soybeans depends on the variety. Our research data were similar to those of Biel et al. (2018)proving that the contents of elements in soybean seeds were dependent on the variety. The highest potassium content was found in 'Midori Giant' beans, highest calcium - in 'Sapporomidori' beans, and highest magnesium - in 'Sayamusume' beans (Table 4).

Many researchers indicate that soybean yield depends on environmental conditions (temperature, precipitation) (Mebrahtu and Mohamed, 2006; Hu and Wiatrak, 2012; Zeipina et al., 2017). Hu and Wiatrak (2012) reported that unfavourable environmental conditions harmed the growth, development, and yield of soya. Photoperiod, temperature, and precipitation with delayed planting affect the duration of developmental stages, the number of branches and pods, plant height, leaf area index (LAI), and hence the grain yield. Higher air temperatures in May-June and significantly rainier months of June and July in 2016 contributed to the fact that soybean plants were taller in our experiments compared to those in 2015. The soybean yield is also influenced by agrotechnical factors (e.g., irrigation) (Duppong and Hatterman-Valenti, 2005; Zeipina et al., 2017). Also, the yield depends on the genotype and variety (Duppong and Hatterman-Valenti, 2005; Ngalamu et al., 2013; Zeipina et al., 2017). According to other researchers, both soybean varieties and planting dates influence soybean growth, development, and yield (Shegro et al., 2010, Rehman et al., 2014). Other scientists stated that the 'Midori Giant' cultivar was characterised by higher average seed weight and high yield compared to other cultivars studied (Zhang and Kyei-Boahen, 2007; Carson et al., 2011; Ogles et al., 2016). Contrary to the data collected by those researchers, the 'Midori Giant' soybean variety demonstrated a good yield in our studies (Table 5). However, the most productive were 'Chiba Green' soybean plants.

According to Sirisomboon et al. (2007), green soybeans can be classified into two main categories according to their use: pods with 3 or 2 seeds each, and pods with only 1 seed; the remaining pods are noncommercial (seedless, deformed). In our research, all cultivated soybean varieties formed more pods with 2-3 beans inside. This accounted for $55.7-75.3 \%$ of the total yield per plant, depending on the variety. The highest yield of non-commercial pods was formed by 'Kaohsiung No9' plants (Table 6).

Consumers of edamame prefer bright green pods, two or more beans per pod, and large seed size (Montri et al., 2006). Seed size is one of the soybean quality indicators (Konovsky et al., 1994). Mebrahtu and Mohamed (2006) reported that soybean yields depended on environmental conditions, however, plant height and 100seed weight were more or less stable. According to Ogles and other researchers (2016) who conducted studies of soybean cultivars of different earliness in Central Alabama, the 25-seed weight of soybeans varied depending 
on the cultivar. The data collected by Ogles et al. and our research suggests that the 25 -seed weight depended on the variety. 'Chiba Green' and 'Sayamusume' soybean cultivars had the highest 25-seed weight (Figure 2b).

Genetic and environmental factors have a major influence on the internal quality of soybean seeds (Krishnan, 2000; Medic et al., 2014; Zeipina et al., 2017). Sanchez et al. (2005) indicated that bean quality was dependent on cultivar. Li et al. (2014) found that delayed soya planting harmed both seeds yield and quality. Rao et al. (2002) reported that soybeans were low in fat (13-16\%) but high in protein (33-39\%). Yin and Vyn (2005) found that soybeans averaged about $41 \%$ protein. The protein content of soybeans was depended on the year of cultivation (Carson et al., 2011), planting time (Muhammad et al., 2009; Rehman et al., 2014). However, no significant difference was recorded between protein percentages in different cultivars (Rehman et al., 2014; Shah et al., 2017). In contrast to the data from Shah, Regman, and other authors, and in accordance with Muhammad our studies showed that the soya variety affected on protein content in beans. 'Chiba Green' beans had the highest protein content (Figure 3a).

Soybean seeds are also an important source of carbohydrates (Medic et al., 2014). They contain about $33 \%$ carbohydrates (Hou et al., 2009). Xu et al. (2016) results showed that the 'Asmara' soybean cultivar at the R6 stage had accumulated more carbohydrates compared to the 'Mooncake' cultivar. According to Xu et al. and our data, the carbohydrate content in beans depended on the variety. Significantly higher carbohydrate content was found in 'Kaohsiung No9' soybeans (Figure 3b).

To improve soybean yield, it is important to establish the relationship between yield and quantitative physiological indicators (Sarutayophat, 2012; Nagasuga, 2018). Arshad et al. (2006) reported that the relationship between soybean yield and its components had been investigated, and the results obtained were used by many researchers as a tool in the selection of soybean varieties. The relationship between seed quality (oil, protein, sugar contents), plant height and yield in soybean has also been examined (Yin and Vyn, 2005; Li et al., 2013, Matsou et al., 2016). It has been established that there is no significant difference between protein concentration and seed yield (Yin and Vyn, 2005). Matsou et al. (2016) found that soybean yield was negatively correlated with the pod rate, 100-seed weight, and protein content. The research results of Li et al. (2013) showed that soybean yield was positively correlated with 3 -seed plants $(\mathrm{r}=0.81), 2$-seed plants $(\mathrm{r}=0.76)$ and 100 -seed weight $(r=0.47)$, and negatively correlated with plant height $(r=-0.75)$. In contrast to Yin and Vyn, our data showed a strong correlation $(\mathrm{r}=0.99)$ between yield and protein content in soybeans. However, a moderate correlation $(r=0.54)$ was found between yield and 100 pod weight, and a weak correlation $(r=0.41)$ was found between yield and 25-grain weight. Thus when choosing soybeans and to obtain a higher yield, it is necessary to pay attention to the number of seeds per pod, 100-seed weight, plant height and seed length (Sarutayophat, 2012).

In the summary, vegetable soybean varieties suitable for cultivation under Lithuanian climatic conditions will provide an opportunity to expand the range of protein-rich foods plants not only in Lithuania, but also in countries with similar climates.

\section{Conclusions}

In order to obtain a good green soybean yield, it is necessary to choose varieties that are suitable for growing in that climate condition. All studied soybean varieties are suitable for cultivation under Lithuanian climatic conditions, except for the variety 'Aoshizuku', which did not reach technical maturity and their yield was not assessed. The seeds of all tested soybean varieties were characterized by good internal seed quality. Protein content in the seeds ranged from 32.5 to $36 \%$, carbohydrates - from 16.1 to $17.6 \%$. It can be stated that 'Chiba Green' is the most suitable vegetable soybean variety for cultivation under Lithuanian climatic conditions. The plants of this variety showed higher photosynthetic intensity, and higher chlorophyll and nitrogen balance index (NBI) in leaves. They demonstrated the highest yield per plant, the weight of 100 pods, and protein content in the seeds. 


\section{Authors' Contributions}

JJ designed the work and JJ, AA and VVK wrote the manuscript. All authors read and approved the final manuscript.

\section{Acknowledgements}

This work was carried out within the framework of the long-term research program "Horticulture: agrobiological basics and technologies" implemented by the Lithuanian Research Centre for Agriculture and Forestry. I thank Fredrik Fogelberg (Dept. of Agricultural Engineering, Swedish University of Agricultural Sciences) for the idea and vegetable soya seeds.

\section{Conflict of Interests}

The authors declare that there are no conflicts of interest related to this article.

\section{References}

Arshad M, Ghafoor A, Ali N (2006). Character correlation and path coefficient in soybean Glycine max (L.) Merrill. Pakistan Journal of Botany 38(1):121-130.

Bakal H, Gulluoglu L, Onat BZ, Arioglu H (2017). The effect of growing seasons on some agronomic and quality characteristics of soybean varieties in Mediterranean Region in Turkey. Turkish Journal of Field Crops 22:187196. https://doi.org/10.17557/tjfc.356213.318-323

Biel W, Gawęda D, Jaroszewska A, Hury G (2018). Content of minerals in soybean seeds as influenced by farming system, variety and row spacing. Journal of Elementology 23:863-873. https://doi.org/10.5601/jelem.2017.22.3.1483

Calviño PA, Sadra, VO, Andrade FH (2003). Quantification of environmental and management effects on the yield of late-sown soybean. Field Crops Research 83:67-77. https//doi.org/10.1016/S0378-4290(03)00062-5

Carson LC, Freeman JH, Zhou K, Welbaum G, Reiter M (2011). Cultivar evaluation and lipid and protein contents of Virginia-grown edamame. HortTechnology 21:131-135. https://doi.org/10.21273/HORTTECH.21.1.131

Djanta MKA, Agoyi Etchikinto E, Agbahoungba S, Quenum FJ, Chadare FJ, Assogbadjo AE, ... Sinsin B (2020). Vegetable soybean, edamame: Research, production, utilization and analysis of its adoption in Sub-Saharan Africa. Journal of Horticulture and Forestry 12(1):1-12. https://doi.org/10.5897/JHF2019.0604

Duppong LM, Hatterman-Valenti H (2005). Yield and quality of vegetable soybean cultivars for production in North Dakota. Hort Technology 15:896-900. https://doi.org/10.21273/HORTTECH.15.4.0896

Fehr WR, Caviness CE (1977). Stages of soybean development. Special. Report. 80. Iowa State Univ. Coop. Ext. Serv., Ames. Pp 13. https://lib.dr.iastate.edu/specialreports/87

Guo J, Rahman A, Mulvaney MJ, Hossain MM, Basso K, Fethiere R, Babar MA (2020). Evaluation of edamame genotypes suitable for growing in Florida. Agronomy Journal 112:693-707. https://doi.org/10.1002/agj2.20136

Gupta AK, Kapoor M, Deodhar AD (1976). Chemical and cooking characteristics of vegetable and grain type soybeans. Journal of Food Science and Technology 13:133-137.

Hou A, Chen P, Alloatti J, Mozzoni L, Zhang B, Shi A (2009). Genetic variability of seed sugar content in worldwide soybean germplasm collections. Crop Science 49:903-912. https://doi.org/10.2135/cropsci2008.05.0256

Hu M, Wiatrak P (2012). Effect of planting date on soybean growth, yield, and grain quality: Review. Agronomy Journal 104(3):785-790. https://doi.org/10.2134/agronj2011.0382

Konovsky J, Lumpkin TA, McClary D (1994). Edamame: The vegetable soybean. In: O'Rourke AD (Ed). Understanding the Japanese Food and Agrimarket: a multifaceted opportunity. Haworth Press, Binghamton pp 173-181.

Krishnan HB (2000). Biochemistry and molecular biology of soybean seed storage proteins. Journal of New Seeds 2:1-25. https://doi.org/10.1300/J153v02n03_01 
Lee C, Choi M, Kim H, Yun H, Lee B, Chung Y, Kim R, Choi H (2015). Soybean [Glycine max (L.) Merrill]: Importance as a crop and pedigree reconstruction of Korean varieties. Plant Breeding and Biotechnology 3:179-196. https://doi.org/10.9787/PBB.2015.3.3.179

Li Y, Du M, Zhang Q, Wang G, Hashemi M, al (2013). Correlation and path coefficient analysis for yield and components of vegetable soybean in northeast China. Legume Research 36:284-288. http://doi.org/10.13140/2.1.1792.6408

Li Y, Du M, Zhang Q, Wang G, Jin J, Herbert S, Liu X (2014). Planting date influences fresh pod yield and seed chemical compositions of vegetable soybean. HortScience 49:1376-1380. https://doi.org/10.21273/HORTSCI.49.11.1376

Matsuo N, Fukami K, Tsuchiya S (2016). Effects of early planting and cultivars on the yield and agronomic traits of soybeans grown in southwestern Japan. Plant Production Science 19:370-380. https://doi.org/10.1080/1343943X.2016.1155417

Mebrahtu T, Mohamed A (2006). Genetic variation for green pod yield and quality among vegetable soybean genotypes. Journal of Crop Improvement 16(1-2):113-130. https://doi.org/10.1300/J411v16n01_08

Medic J, Atkinson C, Charles R, Hurburgh Jr (2014). Current knowledge in soybean composition. Journal of the American Oil Chemists' Society 91:363-384 https://doi.org/10.1007/s11746-013-2407-9

Montri DN, Kelley KM, Sánchez ES (2006). Consume interest in fresh, in-shell edadame and acceptance of edadamebased patties. HortScience 41(7):1616-1622. https://doi.org/10.21273/HORTSCI.41.7.1616

Muhammad A, Khalil SK, Marwat KB, Khan AZ, Khalil IH, Amanullah, Arifullah S (2009). Nutritional quality and production of soybean land races and improved varieties as affected by planting dates. Pakistan Journal of Botany 41(2):683-689.

Nagasuga K (2018). Soybean seed production and canopy photosynthesis in cultivation. In: Kasai M (Ed). Soybean Biomass, Yield and Productivity. IntechOpen. pp 41-58. https://doi.org/10.5772/intechopen.81808

Ngalamu T, Ashraf M, Meseka S (2013). Soybean (Glycine max L) genotype and environment interaction effect on yield and other related traits. American Journal of Experimental Agriculture 3(4):977-987.

Nolen S, Zhang B, Kering MK (2016). Increasing fresh edamame bean supply through season extension techniques. Journal of Horticulture 3:170. https://doi.org/10.4172/2376-0354.1000170

Ogles CZ, Guertal EA, Weaver DB (2016). Edamame cultivar evaluation in Central Alabama. Agronomy Journal 108 (6):2371-2378. https://doi.org/10.2134/agronj2016.04.021

Rao MSS, Bhagsari AS, Mohamed AI (2002). Fresh green seed yield and seed nutritional traits of vegetable soybean genotypes. Crop Science 42(6):1950-1958. https://doi.org/10.2135/cropsci2002.1950

Rehman M, Khaliq T, Ahmad A, Wajid SA, Rasul F, Hussain J, Hussain S (2014). Effect of planting time and cultivar on soybean performance in semi-arid Punjab. Pakistan. Academia Journal of Agricultural Research 2(5):134-138. http://dx.doi.org/10.15413/ajar.2014.0123

Sanchez ES, Kelley KM, Butler L (2005). Edamame production as influenced by seedling emergence and plant population. HortTechnology 15(3):672-676. https://doi.org/10.21273/HORTTECH.15.3.0672

Santos JM. Peixoto CP, Rangel MAS, Cruz TV, Silva RNA, Ledo CAS (2013). Agronomic performance of vegetable soybean genotypes cultivated in the recôncavo baiano, Brazil. Revista Brasileira de Ciências Agrárias (Agrária) 8(3):402-407. https://doi.org/10.5039/agraria.v8i3a2441

Sarutayophat T (2012). Correlation and path coefficient analysis for yield and its components in vegetable soybean. Songklanakarin Journal of Science and Technology 34(3):273-277.

Shah T, Zaffar N, Kalsoom, Ahmad A, Jalal A (2017). Yield and quality traits of soybean cultivars response to different planting windows. International Journal of Statistics and Actuarial Science 1(3):55-59. https://doi.org/10.11648/j.ijsas.20170103.11

Shegro A, Atilaw A, Pal UR, Geleta N (2010). Influence of varieties and planting dates on growth and development of soybean (Glycine max L. Merr) in Metekel zone, North Western Ethiopia. Journal of Agronomy 9:146-156. https://doi.org/10.3923/ja.2010.146.156

Sirisomboon P, Pornchaloempong P, Romphophak T (2007). Physical properties of green soybean: Criteria for sorting. Journal of Food Engineering 79:18-22. https://doi.org/10.1016/j.jfoodeng.2006.01.022

Wang ZQ, Senga EFB, Wang DY (2005). Vegetable soybean (Glycine Max (L.) Merrill) from production to processing. Outlook on Agriculture 34(3):167-172. https://doi.org/10.5367/000000005774378766

WRB (2014). World reference base for soil resources 2014. International soil classification system for naming soils and creating legends for soil maps. World Soil Resources Reports No. 106. Rome, FAO pp 187-192. 
Wszelaki AL, Delwiche JF, Walker SD, Liggett RE, Miller SA, Kleinhenz, MD (2005). Consumer liking and descriptive analysis of six varieties of organically grown edadame-type soybean. Food Quality and Preference 16:651-658. https://doi.org/10.1016/j.foodqual.2005.02.001

Xu Y, Cartier A, Kibet D, Jordan K, Hakala I, Davis S, Sismour E, Kering M, Rutto L (2016). Physical and nutritional properties of edamame seeds as influenced by stage of development. Journal of Food Measurement and Characterization. Food Measure 10(2):193-200. https://doi.org/10.1007/s11694-015-9293-9

Yin X, Vyn TJ (2005). Relationship of isoflavones, oil, and protein in seed with yield of soybean. Agronomy Journal 97:1314-1321. https://doi.org/10.2134/agronj2004.0316

Zhang L, Kyei-Boahen S (2007). Growth and yield of vegetable soybean (Edamame) in Mississippi. HortTechnology 17(1):26-31. https://doi.org/10.21273/HORTTECH.17.1.26

Zhang QY, Gao QL, Herbert SJ, Li YS, Hashem, M (2010). Influence of sowing date on phenological stages, seed growth and marketable yield of four vegetable soybean cultivars in Northeastern USA. African Journal of Agricultural Research 5(18):2556-2562.

Zhang Q, Li Y, Chin KL, Qi Y (2017). Vegetable soybean: Seed composition and production research. Italian Journal of Agronomy 12:276-282. https://doi.org/10.4081/ija.2017.872

Zeipiņa S, Alsiṇa, I, Lepse L (2017). Insight in edamame yield and quality parameters: a review. In: Research for Rural Development 2017: Annual 23th International Scientific Conference Proceedings 2:40-45. https://doi.org/10.22616/rrd.23.2017.047

Zeipiņa S, Lepse L, Alsiņa I (2016). Vegetable soybean - edamame. In: Proceedings of the Scientific and Practical Conference "Harmonious Agriculture" 3:148-151.

OPEN ACCESS

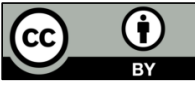

The journal offers free, immediate, and unrestricted access to peer-reviewed research and scholarly work. Users are allowed to read, download, copy, distribute, print, search, or link to the full texts of the articles, or use them for any other lawful purpose, without asking prior permission from the publisher or the author.

License - Articles published in Notulae Botanicae Horti Agrobotanici Cluj-Napoca are Open-Access, distributed under the terms and conditions of the Creative Commons Attribution (CC BY 4.0) License. (C) Articles by the authors; UASVM, Cluj-Napoca, Romania. The journal allows the author(s) to hold the copyright/to retain publishing rights without restriction. 